Article

\title{
Low Host Specialization in the Cuckoo Wasp, Parnopes grandior, Weakens Chemical Mimicry but Does Not Lead to Local Adaption
}

\author{
Carlo Polidori ${ }^{1, *(D)}$, Yolanda Ballesteros ${ }^{2}$, Mareike Wurdack ${ }^{3}\left(\mathbb{D}\right.$, Josep Daniel Asís ${ }^{2}$, \\ José Tormos $^{2}$, Laura Baños-Picón ${ }^{2}$ and Thomas Schmitt ${ }^{3}$ (D) \\ 1 Institute of Environmental Sciences (ICAM), University of Castilla La Mancha. Avda, Carlos III s/n, \\ 45071 Toledo, Spain \\ 2 Zoology Unit, Faculty of Biology, University of Salamanca, 37071 Salamanca, Spain; \\ sandwasp@outlook.com (Y.B.); asis@usal.es (J.D.A.); tormos@usal.es (J.T.); lbanos@usal.es (L.B.-P.) \\ 3 Department of Animal Ecology and Tropical Biology, Biocenter, University of Würzburg, Am Hubland, \\ 97074 Würzburg, Germany; mareike.wurdack@gmail.com (M.W.); thomas.schmitt@uni-wuerzburg.de (T.S.) \\ * Correspondence: carlo.polidori@uclm.es
}

Received: 20 January 2020; Accepted: 18 February 2020; Published: 20 February 2020

\begin{abstract}
Insect brood parasites have evolved a variety of strategies to avoid being detected by their hosts. Few previous studies on cuckoo wasps (Hymenoptera: Chrysididae), which are natural enemies of solitary wasps and bees, have shown that chemical mimicry, i.e., the biosynthesis of cuticular hydrocarbons (CHC) that match the host profile, evolved in several species. However, mimicry was not detected in all investigated host-parasite pairs. The effect of host range as a second factor that may play a role in evolution of mimicry has been neglected, since all previous studies were carried out on host specialists and at nesting sites where only one host species occurred. Here we studied the cuckoo wasp Parnopes grandior, which attacks many digger wasp species of the genus Bembix (Hymenoptera: Crabronidae). Given its weak host specialization, P. grandior may either locally adapt by increasing mimicry precision to only one of the sympatric hosts or it may evolve chemical insignificance by reducing the $\mathrm{CHC}$ profile complexity and/or CHCs amounts. At a study site harbouring three host species, we found evidence for a weak but appreciable chemical deception strategy in P. grandior. Indeed, the CHC profile of $P$. grandior was more similar to all sympatric Bembix species than to a non-host wasp species belonging to the same tribe as Bembix. Furthermore, P. grandior $\mathrm{CHC}$ profile was equally distant to all the hosts' $\mathrm{CHC}$ profiles, thus not pointing towards local adaptation of the $\mathrm{CHC}$ profile to one of the hosts' profile. We conducted behavioural assays suggesting that such weak mimicry is sufficient to reduce host aggression, even in absence of an insignificance strategy, which was not detected. Hence, we finally concluded that host range may indeed play a role in shaping the level of chemical mimicry in cuckoo wasps.
\end{abstract}

Keywords: Chrysididae; Bembix; chemical mimicry; cuticular hydrocarbons

\section{Introduction}

Females of many insect brood parasites sneak into the host nests in order to deposit their eggs or larvae, a behaviour allowing parasites to easily leave chemical traces in the nests. These cues may provoke a defensive response by the hosts, i.e., the abandonment of the nest, the destruction of the parasites' eggs or direct attack to the adult parasite [1-3]. Thus, to reduce the probability of being detected by their hosts during nest invasion, insect brood parasites have evolved different strategies that often prevent recognition via chemical cues [4-7]. These strategies were particularly studied in aculeate Hymenoptera (bees, wasps and ants), a diverse insect group in which parasitism evolved 
independently many times [8-10]. Within the Aculeata, brood parasitoids (females laying eggs on or into the host immatures), kleptoparasites (females laying eggs on the host food resources) and social parasites (reproductive females invading a social host nest and exploiting the worker force of the host colony for breeding) occur [6,8-10].

Chemical strategies to successfully avoid host aggression during nest invasion are common in parasitic aculeate Hymenoptera. They can be grouped into three main categories: (a) chemical mimicry, which occurs when a parasite synthetises de novo an odour bouquet matching that of the host's bouquet [11], (b) chemical camouflage, which occurs when the host odour bouquet is acquired from the host [9] and (c) chemical insignificance, which occurs when the brood parasites have reduced recognition cues, which limit their chance of being perceived by the hosts [12]. All these strategies might have an impact on the evolution of cuticular hydrocarbon (CHC) profiles, i.e., the thin layers of a complex mixture of non-polar substances that covers the whole external surface of insects. Indeed, while the primary function of CHCs is to reduce desiccation, abrasion or infection, they also commonly act as semiochemicals in different contexts of communication, including intra-specific and inter-specific recognition $[7,13]$.

Although these strategies were detected in parasitic aculeate Hymenoptera, it is still unclear which factors may promote such alternative adaptations in an evolutionary context. For example, chemical camouflage was frequently found as a strategy in socially parasitic wasps and ants and to a limited extent in socially parasitic bees $[6,9,14-16]$. Insignificance was observed in many social parasites, too, as parasites tend to show a reduced number of cues at the nest invasion stage, prior to colony integration [6,9], as well as in few solitary brood parasites [12]. On the other hand, mimicry was observed only in few species within the family Chrysididae (cuckoo wasps) [11,17], which include parasitoids or kleptoparasites of wasps and bees [18]. In particular, precise chemical mimicry was recognised in Hedychrum rutilans Dahlbom, 1854, a natural enemy of the wasp Philanthus triangulum (Fabricius, 1775) and to a lesser extent of Philanthus coronatus (Thunberg, 1784), and in Chrysis mediata Linsenmaier, 1951 and Pseudospinolia neglecta (Shuckard, 1837), each attacking only one out of two different chemotypes of the eumenine wasp Odynerus spinipes (Linnaeus,1758) [11,17]. All these cuckoo wasp species enter active, open host nests, making chemical mimicry essential to avoid being detected. However, chemical mimicry was not found in Chrysis viridula Linnaeus, 1761. Females of this species re-open already sealed nests of $O$. spinipes to oviposit [17]. Additionally, evidence for a less precise mimicry was found in Hedychrum nobile (Scopoli, 1763), which attacks several species of the wasp genus Cerceris [11]. Interestingly, the few cuckoo wasp species for which a strong chemical mimicry was detected are all highly specialised in the host choice, suggesting that host range may play a role in shaping chemical strategies. However, strategies that generalist cuckoo wasps may adopt in the presence of several sympatric hosts have not been investigated yet.

Here, we studied the cuckoo wasp, Parnopes grandior (Pallas, 1771). At least 10 Bembix (Hymenoptera: Crabronidae) species are recorded as hosts of this cuckoo wasp [2,19-25], suggesting that it is a brood parasitoid specialist at the genus level. Bembix wasps are Diptera-hunting predators that nest in aggregations in sandy soil, where $P$. grandior often co-occurs [26]. We analysed host-parasite relationships at a Spanish site where three Bembix species (Bembix merceti Parker 1904, Bembix sinuata Panzer 1804 and Bembix zonata Klug 1835) occur. Host relationships between P. grandior and all of these species except from $B$. merceti were confirmed by observing cuckoo wasps emerging from the wasp brood cells [21,24]. Furthermore, P. grandior also visits B. merceti nests (Polidori et al. unpublished data), even sometimes fighting outside nests (J. T, pers. observation). Thus, we consider this species as a potential host. Bembix females frequently bring prey items to the nest during a large part of brood development and check larval growth until it is fully provisioned. Parnopes grandior females oviposit in the host nests during these provisioning flights of host females [24,25]. While host females are able to detect eggs of P. grandior, and, in consequence, abandon their nests [2], cuckoo wasps would be favoured to chemically mimicking their hosts, preventing them from leaving chemical cues. 
Because of its low host specialization, however, $P$. grandior would not be able to chemically match all available hosts at a given location, given that $\mathrm{CHC}$ profiles tend to be species-specific in insects $[7,13]$. In particular, we might document local adaptation to one of the host species as shown in other insect brood parasites, including socially parasitic ants, bee-parasitic beetles and ant-parasitic Lepidoptera [27-29]. Alternatively, P. grandior may maintain a weak mimicry to all present hosts and/or reduce the $\mathrm{CHC}$ profile complexity and/or CHC amounts (insignificance strategy). The latter strategy was also previously observed in parasitic Hymenoptera [30].

We thus tested two alternative hypotheses. The first hypothesis is that the $\mathrm{CHC}$ profile of $P$. grandior weakly overlaps with the CHC profile of any host species (low level of chemical mimicry) and/or presents a less complex profile and/or lower amounts of $\mathrm{CHCs}$ (chemical insignificance). The second hypothesis is that the $P$. grandior population is chemically more similar to just one of the three Bembix species, a strategy that could be explained by local adaptation. To test these hypotheses, we compared the CHCs profile of Bembix spp., P. grandior and a non-host "outgroup" species (Stizus continuus (Klug, 1835) belonging to the same tribe as Bembix (Bembicini) [31]. Furthermore, we performed behavioural assays to investigate whether the hosts can recognise the $\mathrm{CHC}$ profile of $P$. grandior. Finally, in host-parasite arms races, higher parasite prevalence and fitness costs to the hosts may increase recognition ability of the hosts, in turn leading to a higher precision of chemical mimicry in the parasite as a counter adaptation [32,33]. Therefore, we collected data on parasitism rates to evaluate its significance for chemical and behavioural differences.

\section{Materials and Methods}

\subsection{Study Area and Sample Collection}

Field work was carried out at a nesting area of Bembix species nearby the small town of Almarail (province of Soria, Spain) $\left(41^{\circ} 34^{\prime} 50^{\prime \prime} \mathrm{N} 2^{\circ} 22^{\prime} 52^{\prime \prime}\right.$ W, $978 \mathrm{~m}$ of altitude) in July 2011-2013. Females of the non-host species $S$. continuus were collected at a saline-sandy soil nesting site nearby the small town El Saler (Province of Valencia, Spain) (39 $22^{\prime} 57^{\prime \prime} \mathrm{N} 0^{\circ} 19^{\prime} 57^{\prime \prime}$ W, $3 \mathrm{~m}$ of altitude) in June-August 2010 [34]. Bembix merceti, B. sinuata and B. zonata nested in an area of about $4 \mathrm{~km}^{2}$ with overlapping nesting sites [35]. At this location cereal crops with small patches of woodland dominate the landscape. Bembix species nest in old fallow plots [35]. Individuals of Bembix spp. and P. grandior were weighted in the field upon collection with an Ohaus Scout Pro balance to the nearest $0.002 \mathrm{~g}$. Five females per species were collected and analysed. Upon collection, these 25 individuals were frozen and stored at $-20^{\circ} \mathrm{C}$ for the subsequent chemical analyses. A total of 22, 20 and 30 brood cells of, respectively, B. merceti, B. zonata and B. sinuata were excavated at the end of summer 2011 and were kept individually in boxes at $6{ }^{\circ} \mathrm{C}$ until next spring. Once extracted from the fridge, individuals were allowed to eclose. Rate of parasitism per host species was calculated as number of parasitised cells divided by the number of excavated cells.

\subsection{Behavioural Experiments}

We carried out behavioural assays to test if Bembix females are able to recognise P. grandior as a foe and behaves accordingly, i.e., being aggressive. Circle tube experiments were carried out at the hosts' nesting site, placing a parasite and a host (one female of either B. merceti, B. sinuata or B. zonata and one female of $P$. grandior) in a $45 \mathrm{~cm}$-long, $1 \mathrm{~cm}$-wide transparent silicon tube. [36-38]. Host wasps were always allowed to enter first in order to mimic the situation of a host wasp staying in its nest while a cuckoo wasp is entering it. We used each tube only once to avoid odour contamination by previous occupants [39].

Behavioural tests were performed between $900 \mathrm{~h}$ and $1500 \mathrm{~h}$ during the foraging period of hosts and cuckoo wasps. Host females were collected while exiting from or returning to their nests. Cuckoo wasp females were collected while patrolling the nest aggregations or while trying to enter a nest. Individuals were colour marked on the thorax and released after the experiments, so that 
no individuals were used in more than one trial. Eight to 12 trials were performed per each of the three species pairs (for a total of 64 tested individuals). While we kept the individuals in the tubes for $15 \mathrm{~min}$, which is a standard duration for circle-tube experiments [36-38], we noted that the activity decreased or even stopped after 5 to $7 \mathrm{~min}$. Thus, we assessed the first five interactions and their rate (number/time). Aggressive, tolerant and avoidance behaviours were considered. Aggressive interactions occurred when a female curls her abdomen under the thorax with the intention to sting the other female, or when a female clamps the mandibles around the neck, limbs or antenna of the other female. The tolerant interactions include the close-up, non-aggressive contacts, such as accommodating their bodies and passing in opposite directions or stopping at a short distance frontally and gently antennating each other. Finally, the avoidance interactions typically include turn-around movements or backing movements without reverse after a frontal encounter, while increasing distances. All these behaviours and their categorization were defined according with previous studies in Apoidea [36-38]. Behavioural data are available in the Supplementary Table S1.

\subsection{Characterization of the Cuticular Hydrocarbon Profile (CHC)}

To extract cuticular hydrocarbons individuals were allowed to thaw for two minutes. The specimens were immersed in a sufficient amount of $n$-hexane to cover the entire body for $10 \mathrm{~min} .1000 \mathrm{ng}$ of $\mathrm{C} 18$ as an internal standard was added prior to the extraction process. Extracts were concentrated with a gentle stream of $\mathrm{N}_{2}$ to approximately $80-100 \mu \mathrm{L}$ remained and stored at $-20{ }^{\circ} \mathrm{C}$. The specimens were stored in $95 \%$ ethanol and their species identification confirmed. We processed the extracts with a HP 6890 gas chromatograph (GC) coupled to a HP 5973 Mass Selective Detector (MS) (Hewlett Packard, Waldbronn, Germany) or an Agilent 7890/5975 GCMS System. The GC (split/splitless injector in splitless mode for $1 \mathrm{~min}$, injected volume: $1 \mu \mathrm{l}$ at $300{ }^{\circ} \mathrm{C}$ injector temperature) was equipped with a DB-5 Fused Silica capillary column ( $30 \mathrm{~m} \times 0.25 \mathrm{~mm}$ ID, df $=0.25 \mu \mathrm{m}$, J\&W Scientific, Folsom, USA). Helium was used as carrier gas with a constant flow of $1 \mathrm{~mL} / \mathrm{min}$. For both GC/MS, the temperature program starts at $60^{\circ} \mathrm{C}$ with a subsequent increase of $5{ }^{\circ} \mathrm{C} / \mathrm{min}$ until $300^{\circ} \mathrm{C}$ and kept isotherm at $300{ }^{\circ} \mathrm{C}$ for $10 \mathrm{~min}$. An ionization voltage of $70 \mathrm{eV}$ (source temperature: $230{ }^{\circ} \mathrm{C}$ ) was set for the acquisition of the mass spectra by electron ionization (EI-MS).

The software MSD ChemStation G1701EA E.02.02.1431 was used to record and analyse the chromatograms and mass spectra. The MS data base Wiley275 (John Wiley \& Sons, New York, USA), the compound-specific retention time, Kovats indices, and the detected diagnostic ions [40] were used to chemically identify $\mathrm{CHC}$ compounds. For few substances eluting at similar retention times, we combined these compounds and classified them as blends.

Once all peaks were quantified, we omitted all compounds that added less than $0.01 \%$ to the overall relative amount within each species. However, if a compound contributed more than $0.01 \%$ (average across individuals) in a single species, we kept it in all investigated species for the comparative analysis. In a second step, we eliminated all compounds that did not occur at least in $50 \%$ of all individuals within a species. Yet again, if a compound occurs in more than half of the individuals of a single species, we kept it in all species. Chemical data are available in the Supplementary Table S2.

\subsection{Statistical Analysis}

To analyse the behavioural data, we first calculated the median number of interactions per minute across trials, for each of the three behavioural responses (aggressive, tolerant and avoidance), occurring in each species pair. Then, we tested for differences among behavioural responses with the nonparametric Kruskal-Wallis test, followed by post-hoc Dunn's test for pairwise comparisons [41]. The $p$-values obtained from Dunn's procedure were the Bonferroni corrected values. The same test was used to verify if the proportion of the different classes of hydrocarbons (linear alkanes, alkenes, mono- and dimethyl-branched alkanes and alkadienes) differed among species. Differences between the rates of parasitism of Bembix spp. were tested with the Z-test. 
The final matrix of the chemical data included 106 peaks (Appendix A). Prior to the statistical analysis of the chemical data, we transformed all the peak values, to avoid undefined values for peaks with an area of zero, as $\log _{10}(($ relative peak area/geometric mean of relative peak area $)+1)$ [11].

To test for chemical mimicry in P. grandior, we performed a series of multivariate analyses, all based on a Bray-Curtis dissimilarity matrix, which is suitable for zero-inflated datasets [42]. All these analyses do not require a priori grouping of species, meaning that these methods allow pattern formation that are exclusively based on CHC similarities.

First, we performed an agglomerative cluster analysis based on the unweighted pair group method using arithmetic means of Bray-Curtis dissimilarities [42]. Second, we created a network plot, in which nodes (individuals) are connected by edges, with the diameter of nodes proportional to the number of edges connected to it, and the thickness of edges proportional to the CHC profile similarity. In this representation of similarities among individuals of all species, we chose a 50\% similarity cut-off to control the number of edges and increase clarity (i.e., only edges between nodes with more than 50\% similarity are shown) [43]. Third, Bray-Curtis dissimilarities were used for ordinations using non-metric multidimensional scaling analysis (NMDS), which is a non-parametric method that avoids assuming linearity among variables [44] and whose resulting plot shows the spatial distances between individuals (i.e., their chemical distances). In the NMDS, deviations are expressed in terms of "stress", for which values $\leq 0.15$ indicate a good fit of ordination [45]. PERMANOVA (Non-Parametric MANOVA (Multivariate Analysis of Variance) was employed to test for differences among the studied species [46]. The significance is computed by permutation of group membership (9999 replicates). Pairwise PERMANOVA between all pairs of groups was also computed as a post-hoc test. Similarity percentages (SIMPER) were calculated to identify the compounds that predominantly contributed to the Bray-Curtis dissimilarities among all species [47]. SIMPER also provides the dissimilarity values between all pairs of species. We used it, together with the pairwise PERMANOVA, to evaluate how similar the CHC profiles of the cuckoo wasps are in comparison to their hosts.

To verify if cuckoo wasps are chemically insignificant to their hosts, we compared two chemical traits among species. First, we compared the total number of peaks among species as an indication of CHC profile complexity [29]. Second, we compared the overall amount of all CHCs as the sum of all peak areas relative to the area of the linear alkane C18, by correcting for insect body weight (ng of hydrocarbons/mg of insect body weight). These comparisons were tested with the Kruskal-Wallis test, followed by post-hoc Dunn's test for pairwise comparisons (Bonferroni corrected $p$-values).

The statistical analyses were performed in XLSTAT 2008 and in PAST 3.04 (Paleontological Statistics Software Package) [48].

\section{Results}

\subsection{Behavioural Interactions}

The three tested Bembix species showed differences in their responses to the presence of $P$. grandior in the circle tubes. B. zonata was the species that performed the lowest number of interactions per minute (0.7), while the other two species showed similar numbers of interactions with the cuckoo wasp per minute (1-1.1). Most of the recorded interactions involved avoidance behaviour in $B$. sinuata (median per minute across trials: 0.35) (Figure 1A) and B. merceti (0.92) (Figure 1C), while less avoidance behaviour was observed in B. zonata (0.08) (Figure 1B). In the latter species, the highest frequency of tolerant behaviour has been recorded (median per minute across trials: 0.26) (Figure 1B), followed by B. sinuata (0.24) (Figure $1 \mathrm{~A}$ ) and by B. merceti (Figure 1C), in which tolerant behaviour was very rare (0.6). All three species of Bembix showed zero (B. merceti) or low levels of aggression towards the cuckoo wasp (medians per minute across trials: 0.00-0.03) (Figure 1). 

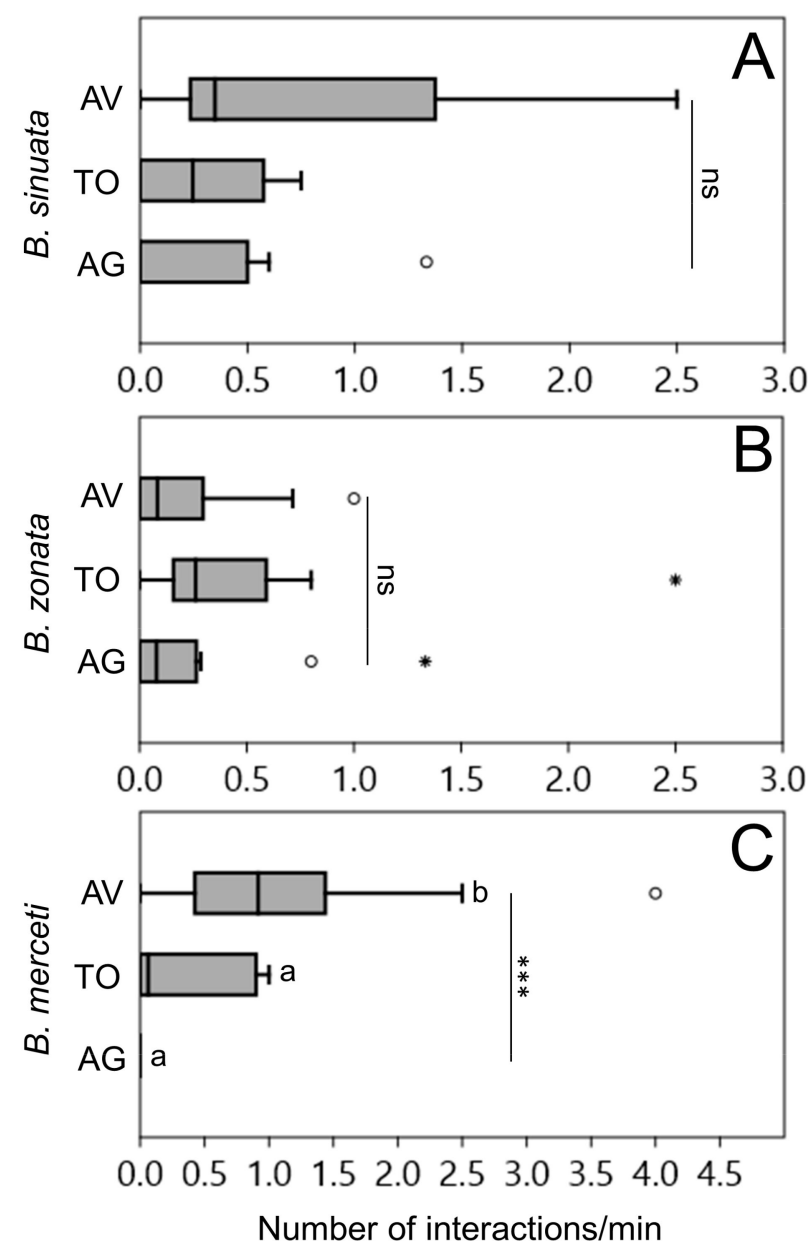

Figure 1. Box-and-whisker plots showing medians (horizontal lines within boxes), $1^{\circ}$ and $3^{\circ}$ quartile (horizontal lines closing the boxes), and maximum and minimum values (ends of the whiskers) for the number of behavioral interactions/minute recorded in circle-tube experiments between the cuckoo wasp P. grandior and its three hosts B. sinuata (A), B. zonata (B) and B. merceti (C). Outliers with a value more than 1.5 times the interquartile range are shown as circles, values with more than three times the interquartile range are shown as stars. ${ }^{* * *}$ means that differences among types of interactions are significant at $p<0.001$; letters identify pairwise differences (Dunn's procedure). AV = avoidance interactions, $\mathrm{TO}=$ tolerant interactions, $\mathrm{AGG}=$ aggressive interactions.

Kruskal-Wallis tests showed no significant differences among median values of aggressive, tolerant and avoidance interactions in B. sinuata $\left(\chi^{2}=2.53, \mathrm{n}=16, p=0.26\right)$ and B. zonata $\left(\chi^{2}=\right.$ $2.98, \mathrm{n}=24, p=0.20)$, while a difference exists in B. merceti $\left(\chi^{2}=16.68, \mathrm{n}=24, p<0.0001\right)$, where avoidance interactions were significantly more frequent (Dunn's test with Bonferroni corrected $p$-values: avoidance vs. tolerant: $p=0.04$, avoidance vs. aggressive: $p<0.0001$, aggressive vs. tolerant: $p=0.13$ ). The three host species did not differ in their aggression levels $\left(\chi^{2}=2.97, \mathrm{n}=16, p=0.10\right)$ (Figure 1).

Rate of parasitism was $0 \%$ in B. merceti $(\mathrm{n}=22), 15 \%$ in B. zonata $(\mathrm{n}=20)$ and $23.3 \%$ in B. sinuata $(\mathrm{n}=30)$. These values were statistically similar $(Z<-1.8, p>0.06)$, except for $B$. merceti, which had a lower parasitism rate than $B$. sinuata $(Z=-2.4, p=0.013)$.

\subsection{Characterization of CHC Profiles}

Linear alkanes, monomethyl-branched alkanes, dimethyl-branched alkanes, alkenes and alkadienes with chain lengths ranging from 20 to 35 carbon atoms occurred as main components on the cuticle of all studied species (Appendix A, Figure 2A). Overall, linear alkanes dominated the CHC profiles of all studied species (43-70\% of relative amount), though with differences (Kruskal-Wallis test, 
$\left.\chi^{2}=20.31, \mathrm{n}=25, p=0.0004\right)$. In particular, in paired comparisons, Bembix spp. did not differ in their relative amount of linear alkanes, while $B$. zonata and B. merceti had higher proportions of linear alkanes than S. continuus, and B. merceti had higher proportions of linear alkanes than P. grandior (Dunn's test with Bonferroni corrected $p$-values: $p=0.002-0.03$ ) (Appendix A, Figure 2A). Dimethyl-branched alkanes were generally rare, occurring in lower proportions $(0.60 \%)$ in $B$. merceti and in a higher proportion $(10.1 \%)$ in S. continuus (Kruskal-Wallis test, $\left.\chi^{2}=18.46, \mathrm{n}=25, p<0.0001\right)$. S. continuus had a significantly higher relative amount of dimethyl-branched alkanes than the other species (Dunn's test with Bonferroni corrected $p$-values: $p=0.002$ ) (Appendix A, Figure 2A) (Appendix A, Figure 2A). Alkadienes were also rare, not representing more than $3.6 \%$ of the $\mathrm{CHC}$ composition, and their proportions differed among species (Kruskal-Wallis test, $\chi^{2}=13.39, \mathrm{n}=25, p=0.003$ ); B. merceti had in particular a higher relative amount of alkadienes than B. sinuata (Dunn's test with Bonferroni corrected $p$-value: $p=0.013$ ). The relative amount of alkenes showed a large variation among species (Kruskal-Wallis test, $\chi^{2}=21.61, \mathrm{n}=25, p=0.0002$ ). Notably, all Bembix and P. grandior have $>15 \%$ of alkenes, while $S$. continuus has only $2.8 \%$. However, the non-host species has significantly lower proportion of alkenes only compared with B. sinuata and B. zonata (Dunn's test with Bonferroni corrected $p$-values: $p=0.0001-0.017)$. Additionally, $P$. grandior has a lower relative amount of alkenes than B. sinuata (Dunn's test with Bonferroni corrected $p$-value: $p=0.04$ ) (Appendix A, Figure 2A). Monomethyl-branched alkanes were less abundant $(<7 \%)$ in the $\mathrm{CHC}$ profile of Bembix, while they exhibit high proportions in P. grandior and in S. continuus $(>40 \%)$ (Kruskal-Wallis test, $\chi^{2}=19.72, \mathrm{n}=25$, $p=0.0005$; Dunn's test with Bonferroni corrected $p$-values: $p=0.001-0.015)$ (Appendix A, Figure 2A).

The total number of $\mathrm{CHC}$ peaks per species, which overall ranged from 32 (B. sinuata) to 67 (B. merceti), differed significantly among species (Kruskal-Wallis test, $\chi^{2}=13.41, \mathrm{n}=25, p=0.003$ ), with B. merceti having the highest number of peaks (Dunn's test with Bonferroni corrected $p$-values: $p=0.002$ ). All other pairwise comparisons, including those between $P$. grandior (50 peaks) and its hosts (Dunn's test with Bonferroni corrected $p$-values: $p=0.15-1$ ), were not significant (Figure 2B). The total amount of $\mathrm{CHCs}$ relative to body mass $(\mathrm{ng} / \mathrm{mg})$ also differed significantly among species (Kruskal-Wallis test, $\chi^{2}=9.65, \mathrm{n}=20, p=0.02$ ), with $B$. sinuata having the highest amount (median = $945 \mathrm{ng} / \mathrm{mg})($ medians $=512-701 \mathrm{ng} / \mathrm{mg})($ Dunn's test with Bonferroni corrected $p$-values: $p=0.013)$. All the other species presented similar amounts (Dunn's test with Bonferroni corrected $p$-values: $p=0.32-1$ ) (Figure 2C). Out of the 50 peaks occurring on $P$. grandior, 22 (mostly linear alkanes) also occurred in all the host species. However, only one of the peaks occurring in $P$. grandior, a rare monomethyl-branched alkane accounting only for the $0.03 \%$ of the $\mathrm{CHC}$ profile, was absent from all Bembix spp., i.e., P. grandior does not possess high amounts of exclusive compounds. On the contrary, P. grandior possesses many substances (21) that lacked in the non-host species, S. continuus.

A network plot (Figure 3A) and a cluster analysis (Figure 3B) showed that the Bembix species have more similar CHC profiles (in terms of Bray-Curtis distances) among them and with P. grandior, compared with the much weaker connections (i.e., higher dissimilarities) with S. continuus. In the network plot, the $50 \%$ similarity cut-off even isolated S. continuus from all the other species (no connections shown) (Figure $3 \mathrm{~A}$ ), while in the cluster analysis S. continuus constitutes the group with the most distant $\mathrm{CHC}$ profile (first bifurcation) (Figure $3 \mathrm{~B}$ ). In the cluster analysis, a second bifurcation separated B. merceti, B. zonata (all individuals except one) and P. grandior from B. sinuata (and the remaining individual of $B$. zonata), while the third bifurcation separated B. zonata from $P$. grandior + B. merceti (Figure 3B). Thus, Bembix spp. were overall chemically more similar to P. grandior than to the phylogenetically closer digger wasp species $S$. continuus. 

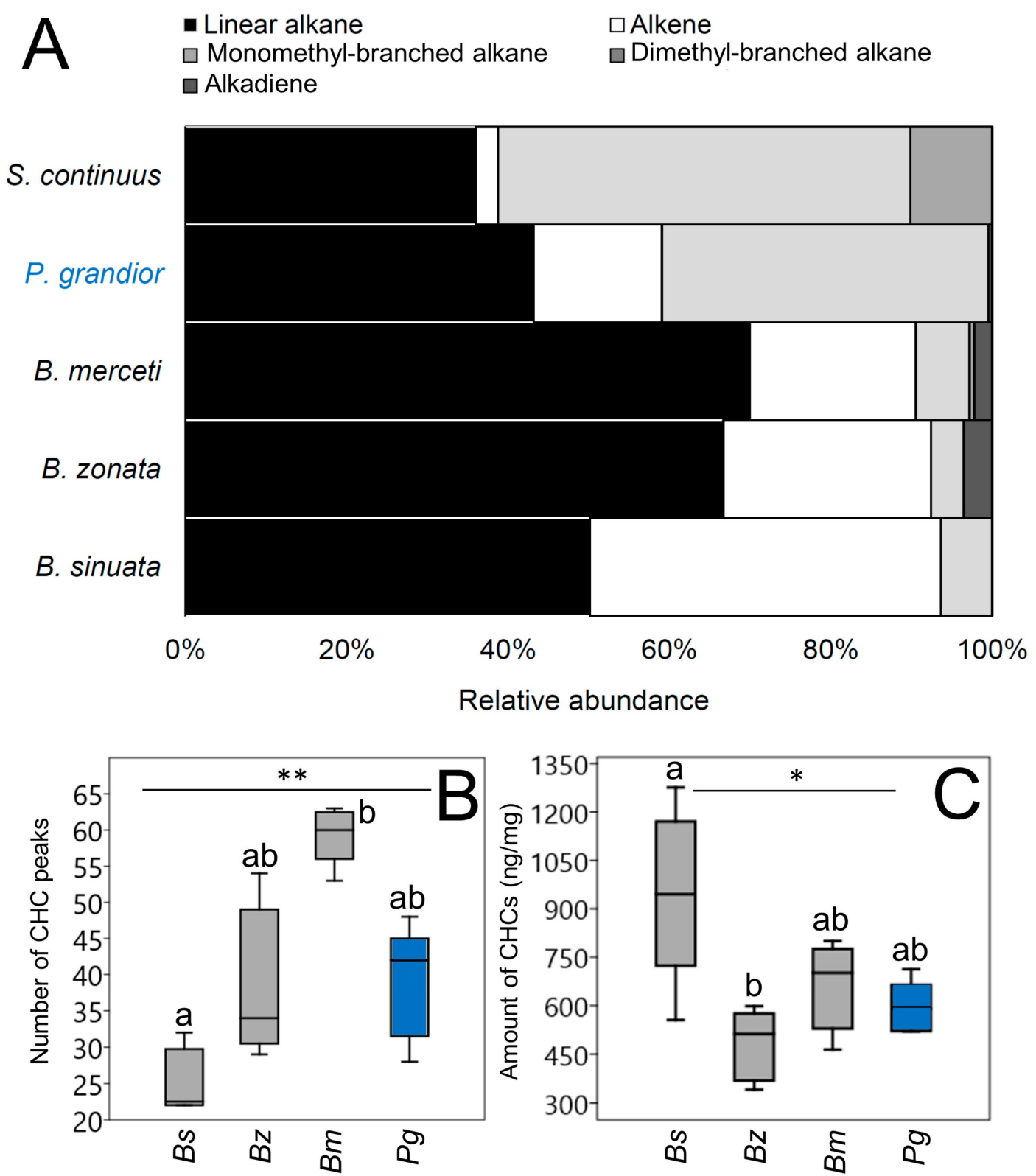

Figure 2. (A) Relative amount (in \%) of the hydrocarbons substance classes in the cuticular hydrocarbon (CHC) profiles of P. grandior (in blue), its Bembix hosts and the non-host S. continuus (all in black); (B) Box-and-whisker plots showing medians (horizontal lines within boxes), $1^{\circ}$ and $3^{\circ}$ quartile (horizontal lines closing the boxes) and maximum and minimum values (ends of the whiskers) for the number of CHC peaks occurring in P. grandior and its Bembix hosts; (C) Box-and-whisker plots showing medians (horizontal lines within boxes), $1^{\circ}$ and $3^{\circ}$ quartile (horizontal lines closing the boxes) and maximum and minimum values (ends of the whiskers) for the amount of CHCs (nm/mg) on the cuticle of $P$. grandior and its Bembix hosts. * and ${ }^{* *}$ mean that differences among groups are significant at $p<$ 0.05 and $p<0.01$, respectively; letters identify pairwise differences (Dunn's procedure). Bs $=B$. sinuata, $\mathrm{Bz}=$ B. zonata, $\mathrm{Bm}=$ B. merceti, $\mathrm{Pg}=$ P. grandior. 


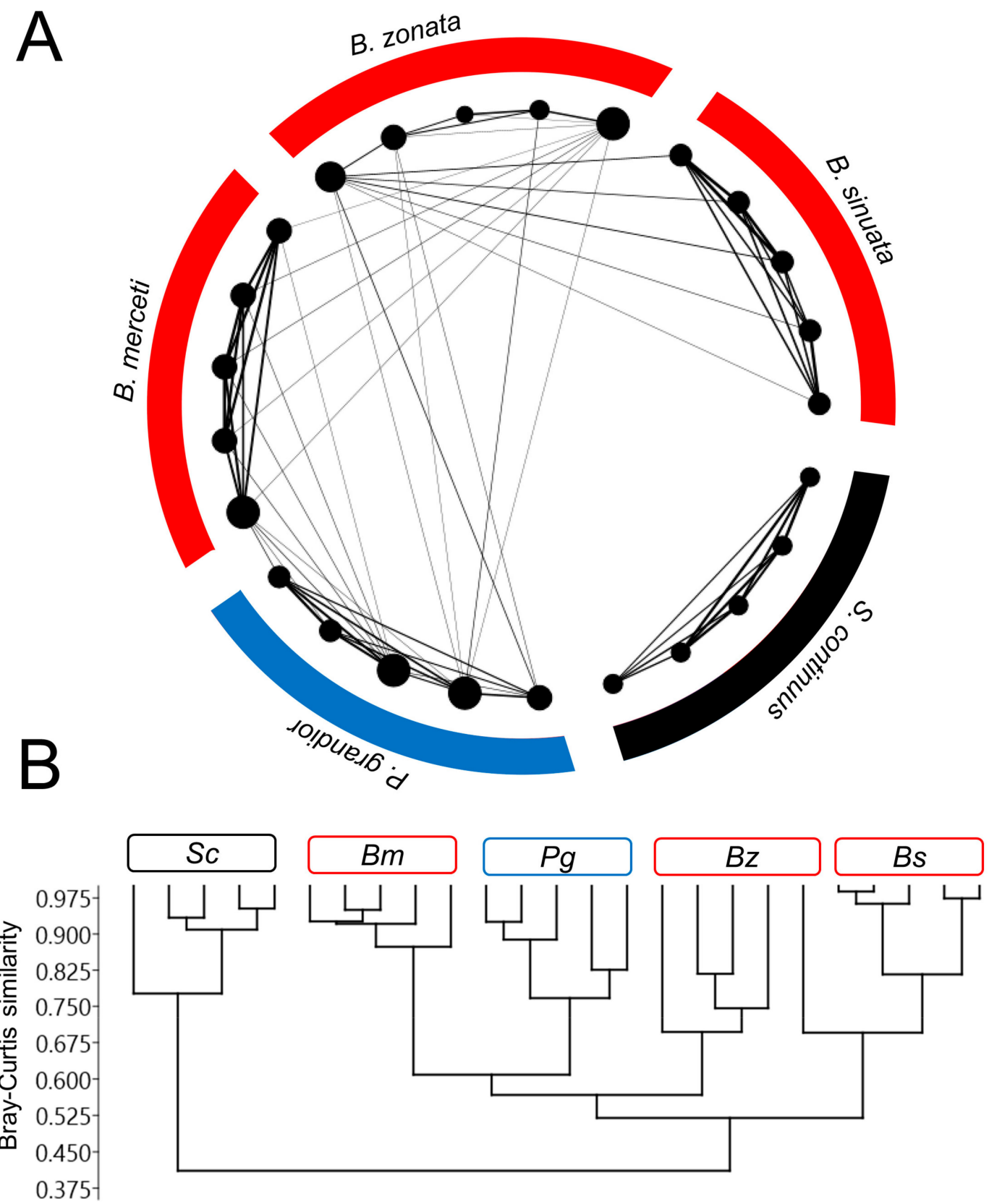

Figure 3. (A) Network plot based on Bray-Curtis distances showing the similarities among all individual CHC profiles of $P$. grandior, its Bembix hosts, and the non-host $S$. continuus. Only edges connecting individuals (i.e., nodes) with $>50 \%$ similarity in their $\mathrm{CHC}$ profiles are shown. The diameter of nodes is proportional to the number of edges connected to it, and the thickness of edges is proportional to the similarity. (B) Dendrogram based on the agglomerative cluster analysis (Bray-Curtis distances) of all individual CHC profiles of $P$. grandior, its Bembix hosts, and the non-host $S$. continuus. Bs $=B$. sinuata, $\mathrm{Bz}=$ B. zonata, $\mathrm{Bm}=$ B. merceti, $\mathrm{Pg}=P$. grandior, $\mathrm{Sc} \_\mathrm{S}=S$. continuus .

The NMDS revealed species-specific $\mathrm{CHC}$ profiles (stress $=0.15)($ PERMANOVA: $\mathrm{F}=27.82$, total sum of squares $=2.74$, within-group sum of squares $=0.41, p<0.0001$ ) (Figure $4 \mathrm{~A})$. Indeed, all pairwise PERMANOVA tests were significant $(\mathrm{F}=10.12-94.15, p<0.01)$. The SIMPER analysis showed that pairwise distances were highest between $S$. continuus and all the other species (57.3-67.6), while lower distances were found among Bembix species (43.0-54.5) and among P. grandior and its hosts (39.1-45.1) (Figure 4B). The SIMPER analysis revealed that the substances contributing to more than $1 \%$ of $\mathrm{CHCs}$ dissimilarities among species (38 substances for a total of $52.7 \%$ of contribution) were 
alkenes (20 substances for a total of $29.2 \%$ of contribution), followed by monomethyl-branched alkanes (11 substances for a total of $14.8 \%$ of contribution) (Figure 4C). Alkadienes and linear alkanes were less important (3-4 substances and 3.3-5.3\% of contribution, respectively) (Figure 4C). Dimethyl-branched alkanes were not important $(<1 \%$ contribution).

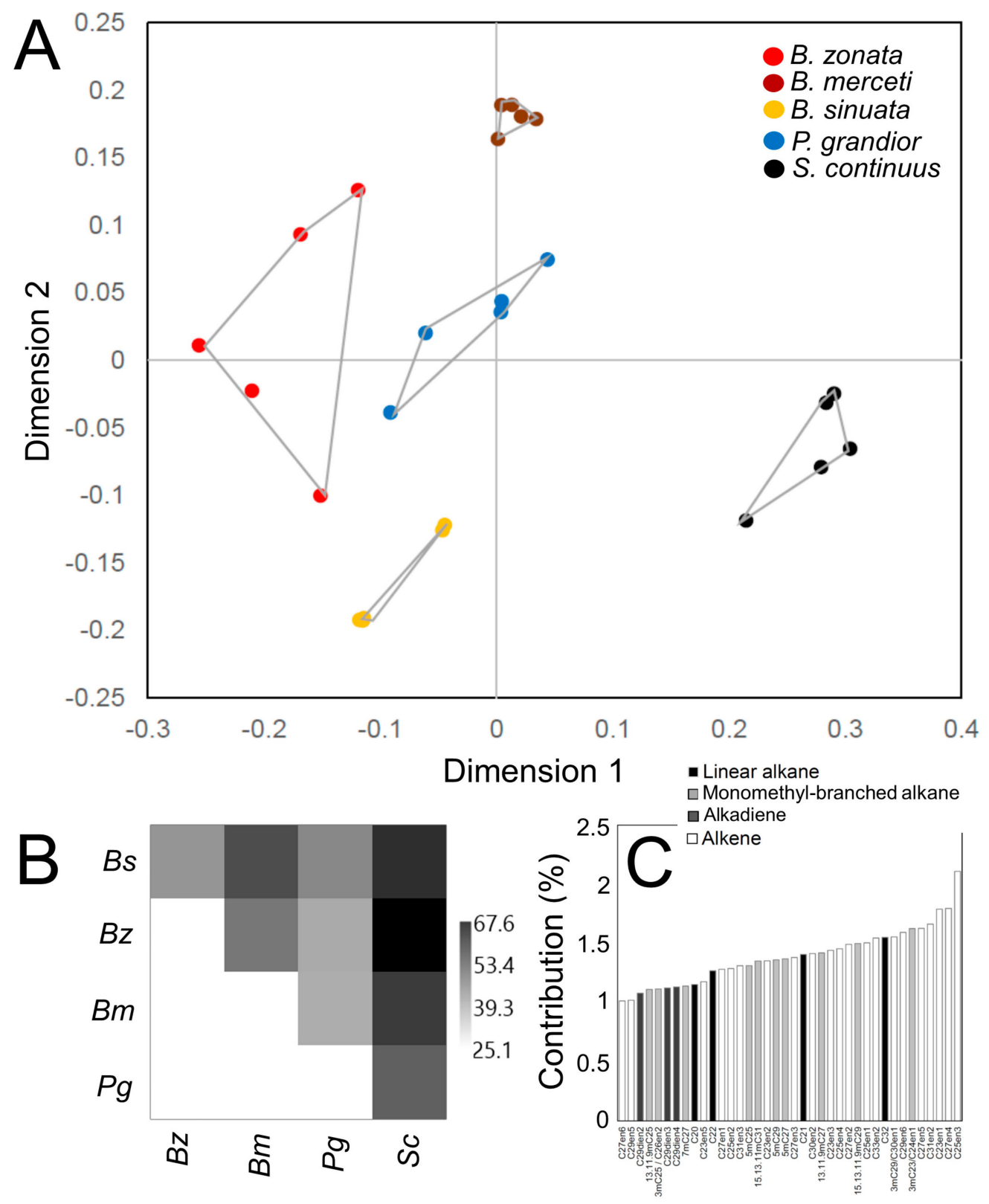

Figure 4. (A) Non-metric multidimensional scaling (NMDS) based on Bray-Curtis distances of all individual CHC profiles of P. grandior, its Bembix hosts, and the non-host S. continuus. (B) Matrix plot showing SIMPER (similarity percentages) dissimilarities among all the studies species. (C) Histogram showing all substances with $>1 \%$ contribution to the SIMPER dissimilarity among the studied species and their relative amount contributing to $\mathrm{CHC}$ profiles; white, light grey, dark grey and black bars correspond to substances of different groups (alkenes, mono- and dimethyl-branched alkanes, alkadienes and linear alkanes). $\mathrm{Bs}=B$. sinuata, $\mathrm{Bz}=$ B. zonata, $\mathrm{Bm}=$ B. merceti, $\mathrm{Pg}=P$. grandior, $\mathrm{Sc}=$ S. continuus. 


\section{Discussion}

It is likely that the dependence of insect brood parasites on their hosts imposes selection on the latter to avoid being recognised by the hosts, and such selection often involves the modification of host recognition cues, such as CHCs $[6,11,49,50]$. Such modification may involve chemical mimicry, chemical insignificance or chemical camouflage. Our study aimed to investigate which chemical strategy may be adopted by $P$. grandior, a cuckoo wasp species that is known to attack several host species even at a single nesting site [34], and, hence, may be limited in precisely matching its CHC profile with those of the hosts. In fact, CHC profiles are often species-specific in insects [13,47]. Indeed, while many parasites specialise in a single or very few host species and consequently closely adapt their behaviour, morphology and chemistry to them [51-53], more generalist parasites face a trade-off. For example, the adaptation to one of the available hosts (i.e., local adaptation by CHC matching with one host) may entail costs for the interactions with the other hosts [54]. On the other hand, using different hosts may entail costs related with a weaker deception strategy, i.e., CHC matching may be weak to all available hosts, and consequently, parasites may be recognised and counter-attacked by their hosts. The latter strategy may, however, be facilitated by reducing in parallel the CHC profile complexity and/or amount (insignificance) [30]. Here, we provide evidence that $P$. grandior evolved a weak but appreciable chemical mimicry strategy, albeit not in conjunction with an insignificant strategy, and that local adaptation seems unlikely.

While both quantitative and qualitative differences were found among the studied species, our data revealed that the CHC profile of $P$. grandior has a shorter chemical distance to all of its Bembix hosts studied compared with the larger chemical distance observed to a non-host species, S. continuus, which is also from the tribe Bembicini. This strongly suggests that the cuckoo wasp chemically matches all the host species to a certain extent. In particular, $P$. grandior overall presents a CHC profile that almost does not include exclusive compounds. While cuckoo wasps lacked many compounds found in the hosts, they do not possess compounds lacking in all hosts, except one rare monomethyl-branched alkane. On the other hand, many compounds found in the cuckoo wasps are not present in S. continuus. The main differences in the CHC profile among the studied species largely rely on alkenes, a class of hydrocarbons known to be important in communication contexts, including intra- and interspecific recognition $[55,56]$. The inclusion of $S$. continuus in our analysis as "outgroup" species was thus important to reveal patterns of mimicry. Similar results were reported by a study on the chemical strategy of another cuckoo wasp and its host. While studying chemical mimicry of $H$. rutilans towards its host $P$. triangulum, the inclusion of the non-host but closely related species Cerceris arenaria (Linnaeus,1758) helped to reject the hypothesis that closer phylogenetic relationships drive closer chemical resemblances between species [11]. We could not include a second species of Chrysididae as outgroup to test the hypothesis that, in case of mimicry, P. grandior would show a larger chemical distance to a closely related cuckoo wasp than to its hosts, as we had no access to other species within the tribe Parnopini. However, by inspecting the $\mathrm{CHC}$ profiles of the cuckoo wasp species studied thus far [11,17], large differences appear compared to P. grandior. In particular, all the other cuckoo wasps present a higher proportion of alkenes compared with linear alkanes, while $P$. grandior possess more linear alkanes than alkenes (as their hosts do) [11,17]. Hence, P. grandior seems to have a CHC profile more similar to its hosts than to other, more closely related, cuckoo wasp species.

As in other studied cuckoo wasp species [11,17], chemical camouflage (CHC matching through host CHC acquisition by the parasite) seems unlikely to explain the similarities found between P. grandior and Bembix spp., since cuckoo wasps have almost no chance to absorb chemicals from hosts or host nests during the short period of nest invasion. Moreover, a camouflage strategy would lead to the absorption of the entire CHC profile of the host. However, P. grandior lacked many compounds found on its hosts. Chemical camouflage was indeed found in most studies on social parasites, where, after nest invasion, colony integration and host odour absorption last for days $[15,16]$.

As expected by its wide host range with at least 10 species of Bembix [2,19-25], the chemical mimicry of $P$. grandior could not be as precise as in other cuckoo wasp species which are either 
specialised in attacking a single host (C. mediata and P. neglecta) or have strong preference to one of only two hosts (H. rutilans) [11,17]. Our results may resemble more what was previously found in $H$. nobile and its host $C$. arenaria [11], probably because $H$. nobile is known to attack at least four Cerceris species [23,53]. Additionally, the lower level of mimicry in H. nobile may also depend on the fact that its host species possess a larger interspecific $\mathrm{CHC}$ profile differences, compared with the hosts of $H$. rutilans [57]. Our results were also similar to those found by Brandt et al. [58] on the socially parasitic ant, Temnothorax (= Protomognathus) americanus (Emery, 1895), and its several sympatric host species (Temnothorax spp.). As in our study, T. americanus had a CHC profile that appeared to be intermediate between sympatric host species. Similarly, Nash et al. [59] found that the CHC profiles of the socially parasitic caterpillars of Phengaris (= Maculinea) alcon (Denis \& Schiffermüller, 1775) did not display host specificity when two species of Myrmica were available at the same site, and that their profile appeared to be a blend of cues from both hosts.

Our behavioural data support a mimicry strategy, since aggressive behaviours of Bembix spp. towards P. grandior under experimental conditions were less frequent compared to the frequency of tolerant or avoidance behaviours. A similar low level of aggression was observed in P. triangulum towards $H$. rutilans inside real ground nests [11], hence, suggesting that the use of circle tubes is an adequate method to assess the host's recognition ability to natural enemies. Thus, even such moderate $\mathrm{CHC}$ matching with hosts seems sufficient in avoiding strong aggression by hosts and thus in successfully parasitizing host nests. Chemical camouflage and insignificance were also reported to reduce host aggression against parasites (camouflage, e.g., Polistes social parasites [9,60]; insignificance, e.g., Sphecodes cuckoo bees [30]). We did not find differences in the aggression level among the host species of $P$. grandior, all of them having perhaps a similar low ability to recognise cuckoo wasps in their nests. Similarly, the sweat bee Lasioglossum malachurum (Kirby, 1802) is pacific towards the cuckoo bee $S$. monilicornis in circle-tubes, but attacks its parasite outside its nests $[3,30]$. The similarity in aggression level towards P. grandior correlates with the similar chemical distances between $P$. grandior and all of its hosts. Interestingly, however, B. merceti had the lowest (null) parasitism rate and showed the lowest (null) aggression level towards the cuckoo wasp. This fits to the scenario of an arm-race expecting that lowering costs for hosts lead to lower recognition ability in their hosts [32]. Further data are needed to understand whether $P$. grandior prevalence is really acting as a driving force for increasing recognition abilities in more heavily attacked host species, and to test whether under such circumstances a higher precision of parasite mimicry appears.

We did not find evidence that $P$. grandior evolved chemical insignificance in addition to chemical mimicry. Mimicry and insignificance may co-occur in parasitic insects, since the latter adds concealment and further decreases recognition cues. Chemical insignificance was previously reported among many social parasitic Hymenoptera at the invasion stage, i.e., prior to colony integration and hence camouflage, including obligate social inquiline bumblebees (Bombus) [61], socially parasitic ants [15] and socially parasitic wasps [9]. Insignificance was also recently found in solitary cuckoo bees in the genus Sphecodes [30]. Chemical insignificance can be achieved by reducing the CHC profile complexity. For example, the cuckoo bee Sphecodes molinilicornis (Kirby, 1802) and the velvet ant Mutilla europea Linnaeus, 1758, and (before host colony invasion) socially parasitic Polistes wasps and socially parasitic ants tend to have a lower number of CHCs than their hosts (halictid bees, Polistes wasps and ants, respectively) $[6,12,15,30,62]$. Furthermore, chemical insignificance may be also achieved by reducing the amount of hydrocarbons $[12,58,63]$. In addition, chemically insignificant profiles have often a reduced number of substances or even lack entire substance classes important for host recognition (e.g., alkenes) $[15,30,64]$. None of these strategies could be revealed in P. grandior: the CHC profile of the cuckoo wasp has a number of compounds and a total CHCs amount that fall in the range observed of their hosts, and possess abundant alkenes (important for recognition). This is in accordance with the results of a study on the cuckoo wasps C. mediata and P. neglecta [17], but is in contrast to what was found in another cuckoo wasp, H. rutilans, where insignificance (as a reduction of CHCs amount) co-occurred with mimicry [65]. 
It has been proposed that the outcome of an arms race between parasites and their hosts is the specialization of the parasite to just one host species [4,66], given that a successful parasite requires specialised adaptations to host recognition $[6,9,67]$. Thus, generalist parasites may be expected to specialise to a single host species at a local scale (local adaptation). This was shown in some socially parasitic ants. For example, both Torres et al. [29] and Bauer et al. [68] found that slave-making ants (Polyergus mexicanus Forel, 1899 and Harpagoxenus sublaevis (Nylander, 1849), respectively) attack almost exclusively only one of the sympatric ant host species. These locally specialised parasites can be easily distinguished by their different CHC profiles. Similar strategies were also revealed in non-hymenopteran parasites of Hymenoptera hosts. For example, Casacci et al. [28] found that parasitic caterpillars (Phengaris (=Maculinea) rebeli (Hirschke, 1904)) show local variations in host (Myrmica ants) specificity, which are consistent with CHC similarities between hosts and parasites at different sites. Local adaptations in chemical deceptive signals were also detected in the parasitic beetle Meloe franciscanus Van Dyke, 1928 attacking two allopatric populations of Habropoda solitary bees [27]. However, we did not find evidence for local adaptation in P. grandior. Indeed, chemical distances between the cuckoo wasp and its hosts were similar. Thus, this cuckoo wasp does not seem to locally adapt by increasing CHC matching with one of the sympatric available hosts. This could be at least partially explained by the rate of parasitism by $P$. grandior, which was not very different between host species.

\section{Conclusions}

Our study investigated the chemical strategy adopted by a generalist chrysidid cuckoo wasp that can chose between more than one host species in a population. We tested two hypotheses: first, $P$. grandior shows a weak chemical mimicry to all its hosts (possibly in conjunction with a reduction of chemical cues in the parasite), and second, the cuckoo wasp shows a local adaptation with a more precise chemical mimicry to one of the available hosts. We found support for the first hypothesis: the low specialization in host use of $P$. grandior lead to a low-level, albeit appreciable chemical mimicry allowing it to successfully attack any of its available host species. A large comparative study is needed to finally test the hypothesis that host range in cuckoo wasps effectively correlates with the precision of chemical mimicry, as previously found in other insect brood parasites of Hymenoptera [69].

Supplementary Materials: The following are available online at http://www.mdpi.com/2075-4450/11/2/136/s1, Table S1: Raw behavioural data, Table S2: Raw chemical data.

Author Contributions: Conceptualization, C.P., Y.B. and T.S.; data curation, C.P. and M.W.; formal analysis, C.P., Y.B., M.W., L.B.-P. and T.S.; funding acquisition, C.P., J.D.A., J.T. and T.S.; investigation, C.P., Y.B., M.W., J.D.A., J.T., L.B.-P. and T.S.; methodology, C.P., Y.B., M.W., J.D.A., J.T. and T.S.; resources, C.P., J.D.A., J.T. and T.S.; writing-original draft, C.P.; writing—review and editing, C.P., M.W. and T.S. All authors have read and agreed to the published version of the manuscript.

Funding: This work was supported by the Projects SA094A09 and SA010A06 (Junta de Castilla y León, Spain), CGL2010-16730 (MICINN, Spain) and CGL2017- 83046-P (MINECO, Spain). Y.B. was funded by a Universidad de Salamanca-Santander Bank grant. C.P. was funded by a post-doctoral contract funded by Universidad de Castilla La Mancha and the FSE.

Acknowledgments: We thank the Junta de Castilla y León for releasing the permits to collect the specimens at the Spanish site.

Conflicts of Interest: The authors declare no conflict of interest. 


\section{Appendix A}

Table A1. Mean value \pm standard error of the relative peak area (\%) of substances (only those that make up $>0.01 \%$ per individual and are present in at least half of the group, see Methods) in the cuticular hydrocarbon profiles of the five studied species. The retention index (RI) for each peak is shown.

\begin{tabular}{|c|c|c|c|c|c|c|}
\hline Substance & RI & B. sinuata & B. zonata & B. merceti & P. grandior & S. continuus \\
\hline C20 & 2000 & $0.01 \pm 0.01$ & $0.03 \pm 0.01$ & $0.03 \pm 0.00$ & $0.02 \pm 0.00$ & 0.00 \\
\hline C21en1 & 2073 & 0.00 & $0.24 \pm 0.19$ & 0.00 & $0.01 \pm 0.01$ & 0.00 \\
\hline C21en2 & 2079 & $0.01 \pm 0.01$ & $0.02 \pm 0.02$ & 0.00 & 0.00 & 0.00 \\
\hline C21 & 2100 & $0.07 \pm 0.02$ & $1.73 \pm 0.94$ & $0.04 \pm 0.01$ & $0.25 \pm 0.10$ & 0.00 \\
\hline C22en1 & 2172 & 0.00 & $0.05 \pm 0.04$ & $0.02 \pm 0.02$ & 0.00 & 0.00 \\
\hline C22 & 2200 & $0.06 \pm 0.04$ & $0.07 \pm 0.03$ & $0.05 \pm 0.00$ & $0.06 \pm 0.01$ & 0.00 \\
\hline C23en1 & 2271 & $0.76 \pm 0.10$ & $0.60 \pm 0.44$ & $0.07 \pm 0.02$ & 0.00 & 0.00 \\
\hline C23en2 & 2275 & 0.00 & $1.87 \pm 1.77$ & $0.02 \pm 0.01$ & $0.10 \pm 0.04$ & 0.00 \\
\hline C23en 3 & 2278 & $0.13 \pm 0.04$ & $0.14 \pm 0.04$ & $0.04 \pm 0.01$ & $0.10 \pm 0.05$ & 0.00 \\
\hline C23en5 & 2292 & $0.04 \pm 0.02$ & $0.02 \pm 0.01$ & $0.06 \pm 0.01$ & 0.00 & 0.00 \\
\hline C23 & 2300 & $11.66 \pm 0.40$ & $11.68 \pm 1.74$ & $3.11 \pm 0.22$ & $1.54 \pm 0.41$ & $0.28 \pm 0.04$ \\
\hline $11,9 \mathrm{mC} 23$ & 2333 & $0.04 \pm 0.03$ & $0.01 \pm 0.01$ & $0.02 \pm 0.01$ & $0.01 \pm 0.01$ & $0.01 \pm 0.01$ \\
\hline $5 \mathrm{mC} 23$ & 2348 & $0.02 \pm 0.01$ & 0.00 & $0.14 \pm 0.01$ & $0.01 \pm 0.01$ & $0.01 \pm 0.01$ \\
\hline 3mC23/C24en1 & 2373 & $0.74 \pm 0.06$ & 0.00 & $0.03 \pm 0.01$ & $0.02 \pm 0.01$ & $0.02 \pm 0.01$ \\
\hline C24 & 2400 & $0.58 \pm 0.02$ & $0.32 \pm 0.12$ & $0.18 \pm 0.01$ & $0.12 \pm 0.02$ & $0.08 \pm 0.01$ \\
\hline C25dien3 & 2458 & 0.00 & 0.00 & $0.03 \pm 0.01$ & 0.00 & 0.00 \\
\hline C25dien 4 & 2463 & 0.00 & 0.00 & $0.05 \pm 0.01$ & 0.00 & 0.00 \\
\hline C25en1 & 2469 & 0.00 & $1.21 \pm 0.38$ & $1.18 \pm 0.36$ & $0.05 \pm 0.05$ & 0.00 \\
\hline C25en2 & 2473 & 0.00 & $0.73 \pm 0.73$ & 0.00 & $0.11 \pm 0.04$ & $0.13 \pm 0.05$ \\
\hline C25en 3 & 2477 & $27.17 \pm 1.38$ & $0.26 \pm 0.08$ & $0.38 \pm 0.10$ & 0.00 & 0.00 \\
\hline C25en 4 & 2481 & 0.00 & $0.37 \pm 0.15$ & $0.93 \pm 0.11$ & $0.19 \pm 0.07$ & 0.00 \\
\hline C25en5 & 2485 & 0.00 & 0.00 & 0.00 & 0.00 & $0.01 \pm 0.01$ \\
\hline C25en6 & 2492 & 0.00 & 0.00 & $0.65 \pm 0.09$ & 0.00 & 0.00 \\
\hline C25 & 2500 & $12.70 \pm 0.42$ & $10.45 \pm 1.33$ & $5.57 \pm 0.31$ & $2.49 \pm 0.32$ & $2.08 \pm 0.55$ \\
\hline $13,11,9 \mathrm{mC} 25$ & 2531 & $0.07 \pm 0.05$ & $0.03 \pm 0.01$ & $0.71 \pm 0.08$ & $0.03 \pm 0.01$ & $0.40 \pm 0.16$ \\
\hline $7 \mathrm{mC} 25$ & 2538 & 0.00 & 0.00 & 0.00 & $0.03 \pm 0.01$ & $0.21 \pm 0.11$ \\
\hline $5 \mathrm{mC} 25$ & 2549 & 0.00 & $0.01 \pm 0.01$ & $0.30 \pm 0.03$ & $0.28 \pm 0.08$ & $0.19 \pm 0.06$ \\
\hline 3mC25 / C26en2 & 2574 & $1.07 \pm 0.10$ & $0.07 \pm 0.02$ & $0.12 \pm 0.02$ & $0.06 \pm 0.03$ & $0.91 \pm 0.33$ \\
\hline C26en3 & 2582 & 0.00 & $0.01 \pm 0.01$ & 0.00 & $0.08 \pm 0.03$ & 0.00 \\
\hline 5,15dimC25/C26en3 & 2582 & 0.00 & 0.00 & $0.27 \pm 0.02$ & 0.00 & 0.00 \\
\hline $5,9 / 5,11 / 5,13 / 5,15 \operatorname{dim} C 25$ & 2585 & 0.00 & 0.00 & 0.00 & 0.00 & $0.17 \pm 0.08$ \\
\hline C26en 4 & 2593 & 0.00 & 0.00 & $0.05 \pm 0.01$ & 0.00 & 0.00 \\
\hline C26 & 2600 & $0.29 \pm 0.02$ & $0.54 \pm 0.07$ & $0.89 \pm 0.03$ & $0.81 \pm 0.13$ & $0.66 \pm 0.11$ \\
\hline 3,7dimC25 & 2612 & 0.00 & 0.00 & 0.00 & 0.00 & $0.26 \pm 0.11$ \\
\hline $13,12,11,10,9 \mathrm{mC} 26$ & 2632 & 0.00 & 0.00 & 0.00 & 0.00 & $0.37 \pm 0.10$ \\
\hline 8,10dimC26 & 2641 & 0.00 & 0.00 & 0.00 & 0.00 & $0.18 \pm 0.09$ \\
\hline $6 \mathrm{mC} 26$ & 2652 & 0.00 & 0.00 & 0.00 & 0.00 & $0.02 \pm 0.01$ \\
\hline C27dien1 & 2653 & 0.00 & $0.06 \pm 0.04$ & $0.14 \pm 0.01$ & 0.00 & 0.00 \\
\hline $5 \mathrm{mC} 26$ & 2657 & 0.00 & 0.00 & 0.00 & 0.00 & $0.07 \pm 0.02$ \\
\hline C27dien & 2660 & 0.00 & $0.01 \pm 0.01$ & $0.24 \pm 0.02$ & 0.00 & 0.00 \\
\hline $4 \mathrm{mC} 26$ & 2663 & 0.00 & 0.00 & 0.00 & 0.00 & $0.06 \pm 0.01$ \\
\hline C27en1 & 2665 & 0.00 & $0.82 \pm 0.30$ & $0.47 \pm 0.04$ & 0.00 & 0.00 \\
\hline C27en2 & 2669 & 0.00 & $0.30 \pm 0.19$ & $0.77 \pm 0.25$ & $1.04 \pm 0.41$ & 0.00 \\
\hline C27en3 & 2672 & 0.00 & 0.00 & $0.93 \pm 0.37$ & $0.19 \pm 0.08$ & $2.11 \pm 0.70$ \\
\hline C27en4 & 2676 & $14.39 \pm 1.09$ & $0.76 \pm 0.31$ & $1.02 \pm 0.05$ & $0.72 \pm 0.44$ & 0.00 \\
\hline C27en 5 & 2680 & 0.00 & $0.34 \pm 0.11$ & $4.23 \pm 0.42$ & $1.85 \pm 0.67$ & 0.00 \\
\hline C27en6 & 2691 & 0.00 & 0.00 & $2.61 \pm 0.29$ & 0.00 & $0.11 \pm 0.07$ \\
\hline $4,8 / 4,10 / 4,12 \operatorname{dimC} 26$ & 2693 & 0.00 & 0.00 & 0.00 & 0.00 & $0.06 \pm 0.02$ \\
\hline C27 & 2700 & $4.54 \pm 0.27$ & $18.52 \pm 2.89$ & $29.35 \pm 0.97$ & $22.53 \pm 1.89$ & $14.72 \pm 2.34$ \\
\hline $13,11,9 \mathrm{mC} 27$ & 2731 & 0.060 .04 & $0.02 \pm 0.02$ & $0.87 \pm 0.10$ & $0.31 \pm 0.07$ & $9.97 \pm 1.69$ \\
\hline $7 \mathrm{mC} 27$ & 2737 & 0.00 & 0.00 & $0.01 \pm 0.01$ & $0.03 \pm 0.02$ & $1.86 \pm 0.31$ \\
\hline $5 \mathrm{mC} 27$ & 2748 & 0.00 & $0.02 \pm 0.02$ & $0.29 \pm 0.05$ & $0.08 \pm 0.03$ & $2.70 \pm 0.62$ \\
\hline 9,13/9,15/9,17dimC27 & 2764 & 0.00 & 0.00 & 0.00 & 0.00 & $0.16 \pm 0.07$ \\
\hline C28en1 & 2766 & 0.00 & $0.09 \pm 0.03$ & $0.01 \pm 0.01$ & 0.00 & 0.00 \\
\hline
\end{tabular}


Table A1. Cont.

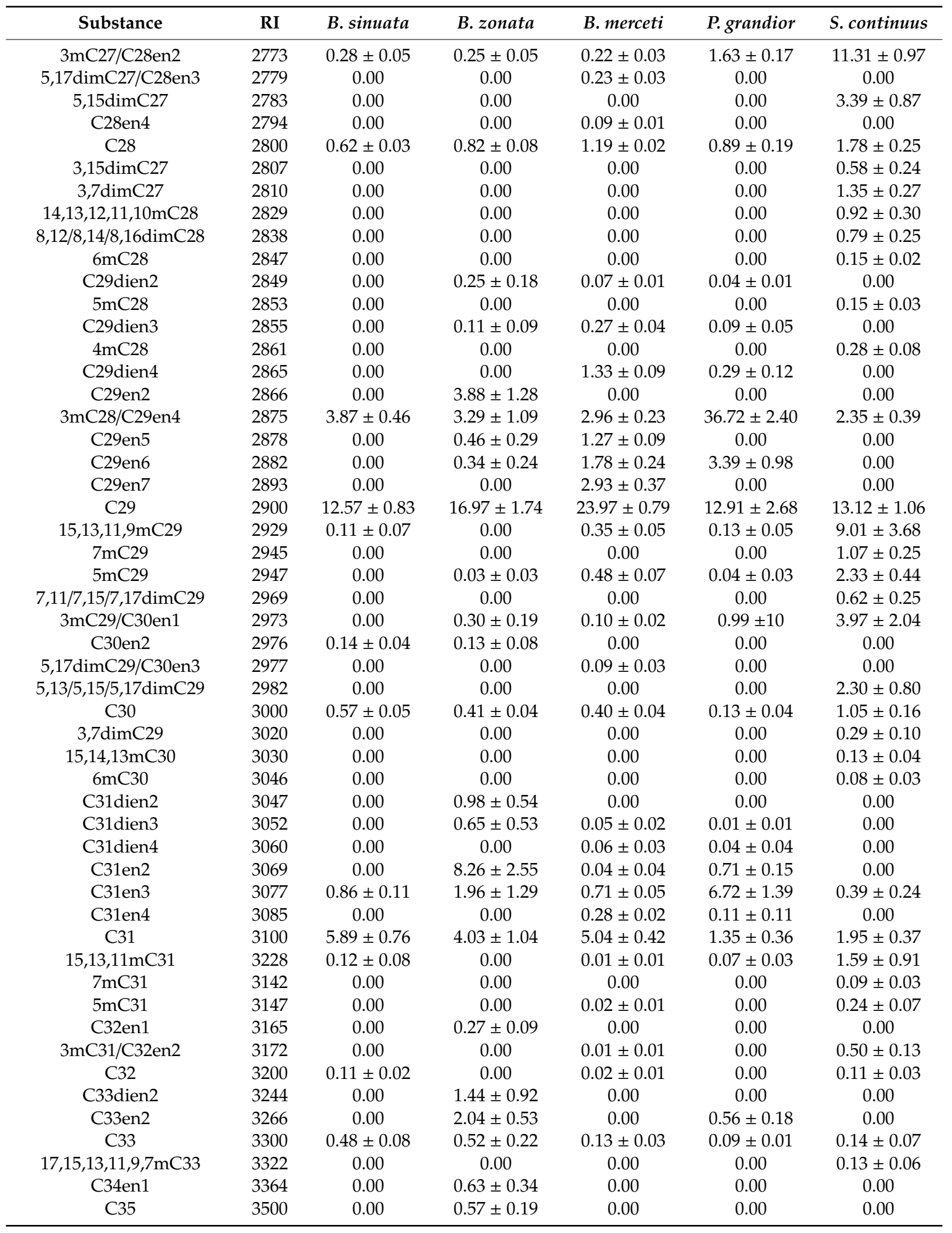

\section{References}

1. Rosenheim, J.A. Parasite presence acts as a proximate cue in the nest-site selection process of the solitary digger wasp, Ammophila dysmica (Hymenoptera: Sphecidae). J. Insect Behav. 1988, 1, 333-342. [CrossRef]

2. Ballesteros, Y.; Tormos, J.; Gayubo, S.F.; Asís, J.D. Notes on the prey, nesting behaviour and natural enemies of three Bembix sand wasps (Hymenoptera: Crabronidae) in the Iberian Peninsula. Annales de la Société Entomologique de France 2012, 48, 281-288. [CrossRef] 
3. Polidori, C.; Borruso, L.; Boesi, R.; Andrietti, F. Segregation of temporal and spatial distribution between kleptoparasites and parasitoids of the eusocial sweat bee, Lasioglossum malachurum (Hymenoptera: Halictidae, Mutillidae). Entomol. Sci. 2009, 12, 116-129. [CrossRef]

4. Schmid-Hempel, P. Parasites in Social Insects; Princeton University Press: Princeton, NJ, USA, 1998; p. 392.

5. Poulin, R.; Morand, S.; Skorping, A. Evolutionary Biology of Host-Parasite Relationships: Theory Meets Reality; Elsevier: Amsterdam, Netherlands, 2000; p. 260.

6. Lenoir, A.; d'Ettorre, P.; Errard, C.; Hefetz, A. Chemical ecology and social parasitism in ants. Annu. Rev. Entomol. 2001, 46, 573-599. [CrossRef] [PubMed]

7. Howard, R.W.; Blomquist, G.J. Ecological, behavioral, and biochemical aspects of insect hydrocarbons. Annu. Rev. Entomol. 2005, 50, 371-393. [CrossRef] [PubMed]

8. O'Neill, K.M. Solitary Wasps: Natural History and Behavior; Cornell University Press: Ithaca, NY, USA, 2001; p. 424.

9. Lorenzi, M.C. The result of an arms race: The chemical strategies of Polistes social parasites. Ann. Zool. Fenn. 2006, 43, 550-563.

10. Michener, C.D. The Bees of the World; The Johns Hopkins University Press: Baltimore, MD, USA, $2007 ;$ p. 992.

11. Strohm, E.; Kroiss, J.; Herzner, G.; Laurien-Kehnen, C.; Boland, W.; Schreier, P.; Schmitt, T. A cuckoo in wolves' clothing? Chemical mimicry in a specialized cuckoo wasp of the European beewolf (Hymenoptera, Chrysididae and Crabronidae). Front. Zool. 2008, 5, 2. [CrossRef]

12. Uboni, A.; Bagnères, A.-G.; Christidès, J.P.; Lorenzi, C.M. Cleptoparasites, social parasites and a common host: Chemical insignificance for visiting host nests, chemical mimicry for living in. J. Insect Physiol. 2012, 58, 1259-1264. [CrossRef]

13. Blomquist, G.J.; Bagnères, A.-G. Insect Hydrocarbons: Biology, Biochemistry and Chemical Ecology; Cambridge University Press: Cambridge, UK, 2010; p. 506.

14. Kreuter, K.; Bunk, E.; Lückemeyer, A.; Twele, R.; Francke, W.; Ayasse, M. How the social parasitic bumblebee Bombus bohemicus sneaks into power of reproduction. Behav. Ecol. Sociobiol. 2012, 66, 475-486. [CrossRef]

15. Johnson, C.A.; Vander Meer, R.K.; Lavine, B. Changes in the cuticular hydrocarbon profile of the slave-maker ant queen, Polyergus breviceps Emery, after killing a Formica host queen (Hymenoptera: Formicidae). J. Chem. Ecol. 2001, 27, 1787-1804. [CrossRef]

16. Cini, A.; Bruschini, C.; Signorotti, L.; Pontieri, L.; Turillazzi, S.; Cervo, R. The chemical basis of host nest detection and chemical integration in a cuckoo paper wasp. J. Exp. Biol. 2011, 214, 3698-3703. [CrossRef] [PubMed]

17. Wurdack, M.; Herbertz, S.; Dowling, D.; Kroiss, J.; Strohm, E.; Baur, H.; Niehuis, O.; Schmitt, T. Striking cuticular hydrocarbon dimorphism in the mason wasp Odynerus spinipes and its possible evolutionary cause (Hymenoptera: Chrysididae, Vespidae). Proc. R. Soc. Lond. B Biol. Sci. 2015, 282, 20151777. [CrossRef] [PubMed]

18. Kimsey, L.S.; Bohart, R.M. The Chrysidid Wasps of the World; Oxford University Press: New York, NY, USA, 1990; p. 664.

19. Berland, L.; Bernard, F. Hyménoptères Vespiformes III (Cleptidae, Chrysidae, Trigonalidae) Faune de France vol.: 34; Office Central de Faunistique. Fédération Française des Société des Sciences Naturelles, Le Chevalier: Paris, France, 1938; p. 145.

20. Grandi, G. Contributi alla conoscenza imenotteri melliferi e predatori. V. Mem. Soc. Entomol. It. 1927, 6, 5-20.

21. Grandi, G. Studi Di Un Entomologo Sugli Imenotteri Superiori; EdiAgricole: Bologna, Italia, 1961; p. 659.

22. Linsenmaier, W. Revision der Familie Chrysididae. Zweiter Nachtrag Mitteilungen der Schweizerischen Entomologischen Gesellschaft. 1968, 41, 1-144.

23. Witt, R. Wespen: Beobachten, Bestimmen; Naturbuch-Verlag: Augsburg, Germany, 1998; p. 359.

24. Asís, J.D.; Gayubo, S.F.; Tormos, J. Data on the nesting behaviour of five European Bembix and description of the mature larvae of B. merceti and B. rostrata (Hymenoptera, Sphecidae). Deut. Entomol. Zschr. 1992, 39, 221-231. [CrossRef]

25. Asís, J.D.; Tormos, J.; Gayubo, S.F. Nesting behaviour and provisioning in Bembix merceti and Bembix zonata (Hymenoptera: Crabronidae). J. Nat. Hist. 2004, 38, 1799-1809. [CrossRef]

26. Evans, H.E.; O'Neill, K.M. The Sand Wasps: Natural History and Behaviour; Harvard University Press: Cambridge, MA, USA, 2007; p. 424. 
27. Saul-Gershenz, L.; Millar, J.G.; McElfresh, J.S.; Williams, N.M. Deceptive signals and behaviors of a cleptoparasitic beetle show local adaptation to different host bee species. Proc. Natl. Acad. Sci. USA 2018, 115, 9756-9760. [CrossRef]

28. Casacci, L.P.; Schönrogge, K.; Thomas, J.A.; Balletto, E.; Bonelli, S.; Barbero, F. Host specificity pattern and chemical deception in a social parasite of ants. Sci. Rep. 2019, 9. [CrossRef]

29. Torres, C.W.; Tonione, M.A.; Ramírez, S.R.; Sapp, J.R.; Tsutsui, N.D. Genetic and chemical divergence among host races of a socially parasitic ant. Ecol. Evol. 2018, 8, 11385-11398. [CrossRef]

30. Polidori, C.; Geyer, M.; Schmitt, T. Do Sphecodes cuckoo bees use chemical insignificance to invade the nests of their social Lasioglossum bee hosts? Apidologie 2019, in press. [CrossRef]

31. Sann, M.; Niehuis, O.; Peters, R.S.; Mayer, C.; Kozlov, A.; Podsiadlowski, L.; Bank, S.; Meusemann, K.; Misof, B.; Bleidorn, C.; et al. Phylogenomic analysis of Apoidea sheds new light on the sister group of bees. BMC Evol. Biol. 2018, 18, 71. [CrossRef] [PubMed]

32. Lorenzi, M.C.; Azzani, L.; Bagnères, A.-G. Evolutionary consequences of deception: Complexity and informational content of colony signature are favored by social parasitism. Curr. Zool. 2014, 60, 137-148. [CrossRef]

33. Ruano, F.; Devers, S.; Sanllorente, O.; Errard, C.; Tinaut, A.; Lenoir, A. A geographical mosaic of coevolution in a slave-making host-parasite system. J. Evol. Biol. 2011, 24, 1071-1079. [CrossRef] [PubMed]

34. Polidori, C.; Giordani, I.; Wurdack, M.; Tormos, J.; Asís, J.D.; Schmitt, T. Post-mating shift towards longer-chain cuticular hydrocarbons drastically reduces female attractiveness to males in a digger wasp. J. Insect Physiol. 2017, 100, 119-127. [CrossRef]

35. Asís, J.D.; Ballesteros, Y.; Tormos, J.; Baños-Picón, L.; Polidori, C. Spatial nest-settlement decisions in digger wasps: Conspecifics matter more than heterospecifics and previous experience. Ethology 2014, 120, 340-353. [CrossRef]

36. Paxton, R.J.; Kukuk, P.F.; Tengö, J. Effects of familiarity and nestmate number on social interactions in two communal bees, Andrena scotica and Panurgus calcaratus (Hymenoptera, Andrenidae). Insect Soc. 1999, 46, 109-118. [CrossRef]

37. Palaban, N.; Davey, K.G.; Packer, L. Escalation of aggressive interactions during staged encounters in Halictus ligatus Say (Hymenoptera: Halictidae), with a comparison of circle tube behaviors with other halictine species. J. Insect Behav. 2000, 13, 627-650. [CrossRef]

38. Boesi, R.; Polidori, C. Nest membership determines the levels of aggression and cooperation between females of a supposedly communal digger wasp. Aggress. Behav. 2011, 37, 405-416. [CrossRef]

39. Bos, N.; Grinsted, L.; Holman, L. Wax On, Wax Off: Nest Soil Facilitates Indirect Transfer of Recognition Cues between Ant Nestmates. PLoS ONE 2011, 6, e19435. [CrossRef]

40. Carlson, D.A.; Bernier, U.R.; Sutton, B.D. Elution patterns from capillary GC for methyl-branched alkanes. J. Chem. Ecol. 1998, 24, 1845-1865. [CrossRef]

41. Zar, J.H. Biostatistical Analysis, 5th ed.; Prentice Pearson Hall: Upper Saddle River, NJ, USA, 2010; p. 960.

42. Leyer, I.; Wesche, K. Multivariate Statistik in der Ökologie; Springer: Berlin, Germany, 2007; p. 232.

43. Fruchterman, T.M.J.; Reingold, E.M. Graph drawing by force-directed placement. Softw. Pract. Exp. 1991, 21, 1129-1164. [CrossRef]

44. McCune, B.; Grace, J.; Urban, D. Analysis of Ecological Communities; MjM Software Design: Gleneden Beach, ORE, USA, 2002.

45. Kruskal, J.; Carroll, J.D. Geometrical models and badness-of-fit functions. In Multivariate Analysis; Krishnaiah, P.R., Ed.; Academic Press: New York, NY, USA, 1969; pp. 639-671.

46. Anderson, M.J. A new method for non-parametric multivariate analysis of variance. Austral Ecol. 2001, 26, 32-46.

47. Clarke, K.R. Non-parametric multivariate analysis of changes in community structure. Aust. J. Ecol. 1993, 18, 117-143. [CrossRef]

48. Hammer, Ø.; Harper, D.A.T.; Ryan, P.D. PAST: Paleontological Statistics Software Package for Education and Data Analysis. Version 2.15. Paleontol. Eletronica 2001, 4, 9. Available online: http://palaeo-electronica.org/ 2001_1/past/issue1_01.htm (accessed on 1 September 2019).

49. Turillazzi, S.; Sledge, M.F.; Dani, F.R.; Cervo, R.; Massolo, A.; Fondelli, L. Social hackers: Integration in the host chemical recognition system by a paper wasp social parasite. Naturwissenschaften 2000, 87, 172-176. [CrossRef] [PubMed] 
50. Leonhardt, S.D.; Menzel, F.; Nehring, V.; Schmitt, T. Ecology and evolution of communication in social insects. Cell 2016, 164, 1277-1287. [CrossRef] [PubMed]

51. Akino, T.; Knapp, J.J.; Thomas, J.A.; Elmes, G.W. Chemical mimicry and host specificity in the butterfly Maculinea rebeli, a social parasite of Myrmica ant colonies. Proc. R. Soc. Lond. B 1999, 266, 1419-1426. [CrossRef]

52. Elmes, G.W.; Barr, B.; Thomas, J.A.; Clarke, R.T. Extreme host specifcity by Microdon mutabilis (Diptera: Syrphidae), a social parasite of ants. Proc. R. Soc. Lond. B 1999, 266, 447-453. [CrossRef]

53. Polidori, C.; Bevacqua, S.; Andrietti, F. Do digger wasps time their provisioning activity to avoid cuckoo wasps (Hymenoptera: Crabronidae and Chrysididae)? Acta Ethol. 2010, 13, 11-21. [CrossRef]

54. Brandt, M.; Foitzik, S. Community context and specialization influence the coevolutionary interactions in a slavemaking ant. Ecology 2004, 85, 2997-3009. [CrossRef]

55. Dani, F.R.; Jones, G.R.; Destri, S.; Spencer, S.H.; Turillazzi, S. Deciphering the recognition signature within the cuticular chemical profile of paper wasps. Anim. Behav. 2001, 62, 165-171. [CrossRef]

56. Dani, F.R.; Jones, G.R.; Corsi, S.; Beard, R.; Pradella, D.; Turillazzi, S. Nestmate recognition cues in the honey bee: Differential importance of cuticular alkanes and alkenes. Chem. Senses 2005, 30, 477-489. [CrossRef] [PubMed]

57. Wurdack, M.; Polidori, C.; Keller, A.; Feldhaar, H.; Schmitt, T. Release from prey preservation behavior via prey switch allowed diversification of cuticular hydrocarbon profiles in digger wasps. Evolution 2017, 71, 2562-2571. [CrossRef] [PubMed]

58. Brandt, M.; Heinze, J.; Schmitt, T.; Foitzik, S. A chemical level in the coevolutionary arms race between an ant social parasite and its hosts. J. Evol. Biol. 2005, 18, 576-586. [CrossRef] [PubMed]

59. Nash, D.R.; Als, T.D.; Maile, R.; Jones, G.R.; Boomsma, J.J. A mosaic of chemical coevolution in a large blue butterfly. Science 2008, 319, 88-90. [CrossRef] [PubMed]

60. Cervo, R. Polistes wasps and their social parasites: An overview. Ann. Zool. Fenn. 2006, 43, 531-549.

61. Dronnet, S.; Simon, X.; Verhaeghe, J.C.; Rasmont, P.; Errard, C. Bumblebee inquilinism in Bombus (Fernaldaepsithyrus) sylvestris (Hymenoptera, Apidae): Behavioural and chemical analyses of host-parasite interactions. Apidologie 2005, 10, 59-70. [CrossRef]

62. Lorenzi, M.C.; Cervo, R.; Zacchi, F.; Turillazzi, S.; Bagnères, A.-G. Dynamics of chemical mimicry in the social parasite wasp Polistes semenowi (Hymenoptera Vespidae). Parasitology 2004, 129, 643-651. [CrossRef]

63. Lorenzi, M.C.; Bagnères, A.G. Concealing identity and mimicking hosts: A dual chemical strategy for a single social parasite? (Polistes atrimandibularis, Hymenoptera: Vespidae). Parasitology 2002, 125, 507-512. [CrossRef]

64. Martin, S.J.; Takahashi, J.; Ono, M.; Drijfhout, F.P. Is the social parasite Vespa dybowskii using chemical transparency to get her eggs accepted? J. Insect Physiol. 2008, 54, 700-707. [CrossRef]

65. Kroiss, J.; Schmitt, T.; Strohm, E. Low level of cuticular hydrocarbons in a parasitoid of a solitary digger wasp and its potential for concealment. Entomol. Sci. 2009, 12, 9-16. [CrossRef]

66. Timms, R.; Read, A.F. What makes a specialist special? Trends Ecol. Evol. 1999, 14, 333-334. [CrossRef]

67. Buschinger, A. Evolution of social parasitism in ants. Trends Ecol. Evol. 1986, 1, 155-160. [CrossRef]

68. Bauer, S.; Böhm, M.; Witte, V.; Foitzik, S. An ant social parasite in-between two chemical disparate host species. Evol. Ecol. 2010, 24, 317-332. [CrossRef]

69. von Beeren, C.; Brückner, A.; Maruyama, M.; Burke, G.; Wieschollek, J.; Kronauer, D.J.C. Chemical and behavioral integration of army ant-associated rove beetles-A comparison between specialists and generalists. Front. Zool. 2018, 15, 8. [CrossRef]

(C) 2020 by the authors. Licensee MDPI, Basel, Switzerland. This article is an open access article distributed under the terms and conditions of the Creative Commons Attribution (CC BY) license (http://creativecommons.org/licenses/by/4.0/). 